Nan D. Hunter

Georgetown University Law Center, ndh5@law.georgetown.edu

This paper can be downloaded free of charge from:

https://scholarship.law.georgetown.edu/facpub/2296

https://ssrn.com/abstract=3644591

Georgetown Law Journal, Vol. 108, Issue 7, Nineteenth Amendment Special Edition, pp. 73-104.

This open-access article is brought to you by the Georgetown Law Library. Posted with permission of the author. Follow this and additional works at: https://scholarship.law.georgetown.edu/facpub

Part of the Civil Rights and Discrimination Commons, and the Law and Gender Commons 


\title{
Reconstructing Liberty, Equality, and Marriage: The Missing Nineteenth Amendment Argument
}

\author{
NAN D. HUNTER*
}

The social movement that led to adoption of the Nineteenth Amendment sought not only women's right to vote but also the end to a system of marriage law based on coverture. Under coverture, married women were deprived of property and contract rights and were de jure subservient to their husbands. Coverture also provided the predicate for denial of the vote. The model voter was the independent yeoman or worker able to express his own interests in a democratic system. Women were thought to be properly confined to the domestic sphere and dependent on their husbands, who were presumed to vote on behalf of all household members. On this understanding, coverture and the state functioned as interlocking systems of governance. The nineteenth century Women's Rights Movement was a campaign to reshape American democracy; eliminating coverture and extending full citizenship rights to women were necessary to achieve that goal. To use a phrase that we now associate with same-sex couples, it was the nation's first marriage equality movement.

Adoption of the Nineteenth Amendment marked a new social understanding that constitutional principles and democratic norms must apply to women's role in marriage as well as to women as citizens. The movement began by articulating a concept of collective liberty, which grew out of experiences in the anti-slavery movement and which expanded on the Founders' more individualist concept of liberty in the Declaration of Independence. After the Civil War, the equality discourse of the Reconstruction Amendments and the rejection of women's demands for the vote by both Congress and the Supreme Court reshaped the dominant theme of women's rights efforts into a campaign for equality. The refusal by federal lawmakers to address women's issues left them no recourse except to lobby state legislators, which women's groups undertook on both suffrage and marriage law. But the diffuse, localized nature of family law presented insuperable barriers to ending coverture in one preemptive action.

The Nineteenth Amendment reflects these dual goals in its text and subtext. The former prohibits denial of the vote based on sex, and the latter, by enabling women's full participation in political life, rebuts the heart of the rationale for coverture: that women's role in society lay solely in the domestic sphere of home and marriage.

Failure to understand the centrality of marriage-law reform to the social and political meaning of the Nineteenth Amendment has impoverished the

\footnotetext{
* Scott K. Ginsburg Professor of Law, Georgetown University Law Center. (c) 2020, Nan D. Hunter.
} 
constitutional grounding for contemporary challenges to the legal regulation of marriage, including the Supreme Court's decision in Obergefell v. Hodges. In Obergefell, which prohibited the exclusion of same-sex couples from marriage, the Court missed an opportunity to draw on the history and meaning of the Amendment to frame the issue as implicating dual systems of governance, both of which must be bound by constitutional principles. Instead, the Court described marriage as a largely prepolitical realm of private, idealized relations. The opinion of the Court failed to comprehend the extent to which marriage today continues to function as an institution of the state and a zone of governance, no longer because of coverture but because it is foundational to the privatization of collective responsibility that is embedded in the nation's primary systems of social insurance.

\section{TABle of CONTENTS}

INTRODUCTION .

I. EMANCIPATION

II. The Charter of American Feminism $\ldots \ldots \ldots \ldots \ldots \ldots \ldots \ldots \ldots \ldots \ldots$

A. THE DEClaRATION ............................ 85

B. COLLECTIVE LIBERTY AND THE BRIDGE TO EQUALITY ......... 86

C. SOCIAL MEANINGS ............................ 89

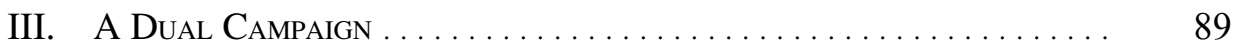

A. FROM SENECA FALLS TO FORT SUMTER ................ 90

B. THE RECONSTRUCTION AMENDMENTS $\ldots \ldots \ldots \ldots \ldots \ldots \ldots \ldots . \ldots \ldots$

C. DOUBLING DOWN ON LIBERAL RIGHTS . . . . . . . . . . . . . . . . 94

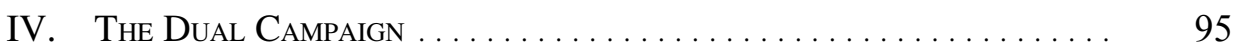

V. Winning One Fight, Continuing the Other............... 98

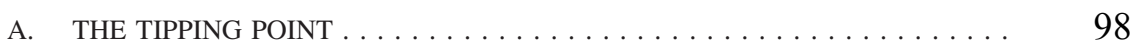

B. EQUALITY AS ONGOING PROCESS ..................... 99

VI. The Nineteenth Amendment in the Twenty-First Century ....... 101

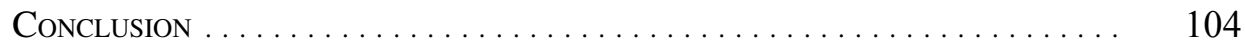




\section{INTRODUCTION}

"In the home is neither freedom nor equality."

A growing body of legal scholarship is grounded in the understanding that the struggle for women's suffrage was about much more than the right to vote. ${ }^{2}$ Those whom we might call the framers of the Nineteenth Amendment-who drafted the first demand that American women be admitted to the franchise and who lobbied for its adoption in the half century after the Reconstruction Amendments - initiated a massive popular mobilization to accord women the full range of political, economic, and social rights that are intrinsic to citizenship. By itself, the change brought by the Nineteenth Amendment fell well short of transformation - both because it conferred only the vote, and because for the millions of black women living in the Jim Crow South when it was adopted in 1920, it failed to convey even that. ${ }^{3}$ But whatever the shortfall between the goals of the most visionary suffragists and the impact of winning the vote, it is nonetheless true that the history of the Nineteenth Amendment offers a rich context for constitutional interpretation related to discrimination based on sex, and one that has widely been overlooked. ${ }^{4}$

In this Article, I argue that beyond its affirmation of women's constitutional equality, there is yet another unmined and underappreciated dimension of the Nineteenth Amendment, one that focuses on its consequences for an institutionmarriage - rather than on its ramifications for women. From the first formulation of the demand for women's suffrage in the 1848 Declaration of Sentiments, winning the vote was both the ends and the means of the campaign for women's rights. The primary end for which suffrage was the means was the transformation of marriage from a quasi-carceral institution structured around the legal subordination and dependency of women to a legal status founded on the mutual association

1. Charlotte Perkins Gilman, The Home: Its Work And Influence 171 (1910).

2. See, e.g., Neil S. Siegel, Why the Nineteenth Amendment Matters Today: A Guide for the Centennial, 27 Duke J. Gender L. \& PoL'y 235, 236 (2020) [hereinafter Siegel, Centennial]; Reva B. Siegel, She the People: The Nineteenth Amendment, Sex Equality, Federalism, and the Family, 115 HARV. L. Rev. 947, 949 (2002) [hereinafter Siegel, She the People]; Reva B. Siegel, The Nineteenth Amendment and the Democratization of the Family, 129 YALE L.J.F. 450, 451 (2020); Tracy A. Thomas, More Than the Vote: The Nineteenth Amendment as Proxy for Gender Equality, STAN. J. Civ. RTs. \& CIV. LIBERTIES (forthcoming 2020) (manuscript at 1), https://papers.ssrn.com/sol3/papers.cfm? abstract_id=3364546 [https://perma.cc/T3BJ-4KTL]; Jennifer K. Brown, Note, The Nineteenth Amendment and Women's Equality, 102 YALE L.J. 2175, 2175 (1993); W. William Hodes, Note, Women and the Constitution: Some Legal History and a New Approach to the Nineteenth Amendment, 25 Rutgers L. REV. 26, 26 (1970).

3. In 1920, there were 9.9 million black people living in the United States, of whom $85 \%$ lived in the South. Frank Hobbs \& Nicole Stoops, U.S. Census Bureau, Demographic Trends in the 20th CENTURY 77 fig.3-4, 83 fig.3-8 (2002), https://www.census.gov/prod/2002pubs/censr-4.pdf [https:// perma.cc/92PD-CW4E]. But by 1908, whites in the South had amended state constitutions and taken other steps to virtually eliminate black voting. Richard H. Pildes, Democracy, Anti-Democracy and the Canon, 17 Const. Comment. 295, 301-04 (2000).

4. Siegel, She the People, supra note 2, at 949-51. 
of free persons. ${ }^{5}$ It was in the early efforts to end coverture, as well as in antislavery societies, that women's demand for suffrage was born. ${ }^{6}$ When the Reconstruction Amendments failed to provide for women's voting rights and the Supreme Court upheld that failure, suffragists embarked on a dual campaign in state legislatures to win ratification of a new amendment and to secure the end of coverture. ${ }^{7}$ When the Nineteenth Amendment was adopted, the primary unfinished business to which the suffragists turned was continuing the effort to change the law of marriage and divorce, ${ }^{8}$ a project not completed until Second Wave feminists secured it from the Supreme Court in the early 1980s. ${ }^{9}$

In today's legal and political thought, the right to vote and the right to equal treatment under law both fall under the rubric of civil rights. But the Declaration of Sentiments as a whole is more an indictment of despotism and a call to reject patriarchy as a form of anti-democratic rule than it is an assertion of women's entitlement to equality. The Declaration was a radical claim for liberty from the legal regime of coverture and its economic and social manifestations. For suffragists, the link between anti-despotism and equality grew from the concept of collective liberty, a goal shared with the anti-slavery movement. A collective theory of liberty was a distinctive variation of the natural rights arguments of the nineteenth century. Suffragists directed this argument most urgently at the institution of marriage.

In the wake of the Civil War, as the center of gravity in the framework for the suffragists' demands shifted to primary reliance on the concept of equality, two facets of an equality claim emerged: one for the equality of women vis-à-vis men and one for equal treatment under law without regard to a woman's marital status. The campaign for the vote sought both. Suffragists understood that the "full achievement of equality for women depended then and still does today upon the transformation of woman's place within the family." 10

In recent years, the most significant applications of rights claims with regard to marriage have arisen from challenges to the denial of access to marriage, especially the exclusion of same-sex couples. At first blush, it may seem paradoxical to base a claim to gain access to an institution in part on a constitutional understanding that was forged in a campaign to empower those who were trapped within that institution. But what unites the two is rejection of the use of state power linked to marriage to produce second-class status, either by subordination

5. Nancy F. Cott, Public Vows: A History of Marriage And the Nation 67 (2000) (quoting Elizabeth Cady Stanton: "this whole question of women's rights turns on the pivot of the marriage relation").

6. See id. at 63-64.

7. See Siegel, She the People, supra note 2, at 973-76, 987, 1034-35.

8. See id. at 1008-09.

9. See Kirchberg v. Feenstra, 450 U.S. 455, 456 (1981) (holding unconstitutional a provision of Louisiana law which vested control of marital property in the husband).

10. Carl N. Degler, At Odds: Women and the Family in America from the Revolution to THE PRESENT 329 (1980). 
within the institution or by exclusion from it. Both of those results create and express status-based inferiority or unworthiness.

The enormous changes in the social functions of marriage that have occurred in the 100 years since the Nineteenth Amendment have produced an institution that remains uniquely powerful but in different ways. In addition to establishing the rights and responsibilities of each partner, the legal system now relies on marriage as an essential part of multiple social insurance systems. It is not an endorsement of the privatization of responsibility for life necessities beyond the resources of individuals to note that important public systems, such as Social Security, and private systems, such as employer-based health insurance, rely on marital status and household composition to structure coverage plans and benefits.

The richer understandings of collective liberty and social equality that grounded the movement to end coverture remain fundamental to contemporary arguments to redefine the law of marriage. Contemporary debates about freedom and equality in the home, to use Charlotte Perkins Gilman's phrasing in the epigraph ${ }^{11}$ build on the achievements of suffragists whose movement understood that marriage was a structure of governance, and insisted that it be made into a subsidiary component of constitutional democracy instead of its own quasisovereign legal realm. The demand for marriage equality in the twenty-first century implicates the right to redefine marriage in ways derivative of the goals sought by the framers of the Nineteenth Amendment.

This Article offers an interpretation of the Nineteenth Amendment to replace the more generic, hybrid liberty-equality principle that the Supreme Court used in Obergefell $v$. Hodges as the basis for invalidating the exclusion of same-sex couples. ${ }^{12}$ It relies on historically grounded understandings of marriage as a legal institution, rather than the largely ahistorical and idealized notions that characterize the opinion in Obergefell. ${ }^{13}$ And it demonstrates the centrality of debates over marriage to the conceptual and political underpinnings of women's suffrage.

In drawing on the texts that suffragists generated, I seek to incorporate the social meaning of what became the Nineteenth Amendment as it was understood during the long campaign for its adoption. The product of this argument is a theory for interpreting a part of our Constitution that has been treated as little more than a procedural correction for the oversight of failing to enfranchise women. ${ }^{14}$ In fact, extending the vote to women required one of history's largest

11. See Gilman, supra note 1, at vii-xi, 171.

12. See 135 S. Ct. 2584, 2604-05 (2015).

13. Id. at 2594 (using references such as "transcendent importance," "nobility and dignity," "unique fulfillment," "our most profound hopes and aspirations," "the beauty of marriage," "timeless," and "the revered idea and reality of marriage").

14. "[W]oman suffrage has too frequently been regarded as an isolated institutional reform. Its character as a social movement, reflecting women's aspirations for and progress toward radical change in their lives, has been overlooked." Ellen Carol DuBois, Feminism and Suffrage: The Emergence OF AN INDEPENDENT WOMEN's MOVEMENT IN AMERICA 1848-1869, at 17 (2d printing, 1980). 
and longest mobilizations for legal personhood, ${ }^{15}$ a campaign that targeted both the official arms of the state and the operations of governance in and through the realm of marriage.

Part I briefly describes the legal context that generated the demand for suffrage. Nineteenth century American women confronted not only the absence of a right to vote but also an almost carceral law of marriage, with its central feature of coverture, the legal regime that had the most direct material impact on early suffragists. The two were linked: the enforced dependency of women within marriage was used to justify the denial of a right to vote. As a result, the demand for the vote was inseparable from a challenge to coverture. ${ }^{16}$

The suffragists' understanding of rights generally and specifically of liberty, which provided the primary intellectual framework for their demands, grew directly from the anti-slavery movement in which many of the early suffragists were active. The women who joined the abolitionist movement prior to the Civil War, and who later led the Nineteenth Amendment campaign, sought a double emancipation - initially of enslaved persons and then also of married women.

Part II focuses on the primary textual and conceptual foundation for the Nineteenth Amendment: the Declaration of Sentiments adopted at the Seneca Falls Convention on women's rights in $1848 .{ }^{17}$ Modeled on the Declaration of Independence, the Declaration of Sentiments was the first formal articulation of the demand for women's suffrage in the United States. ${ }^{18}$ The authors of the Declaration of Sentiments analyzed the web of laws and customs that constituted marriage as an example of authoritarianism. ${ }^{19}$

The women of 1848, like the Founders in 1776, prioritized the vocabulary of freedom and liberty, stated in terms of natural rights. ${ }^{20}$ But beyond the natural rights jurisprudence of the time, they also developed an original collective liberty argument that transcended Lockean individualism. An understanding of liberty as collective as well as individual built a bridge to the equality arguments that characterized contemporaneous advocacy of the Married Women's Property Acts. Thus the first stage of the movement for women's equal rights was emancipatory - the rejection of a divine power claimed by those who ruled families as kingdoms.

15. See Shall Not Be Denied: Women Fight for the Vote, LIBRARY OF CONG., https://www.loc.gov/ exhibitions/women-fight-for-the-vote/about-this-exhibition/ [https://perma.cc/Y5EB-962L] (last visited Apr. 18, 2020).

16. Siegel, She the People, supra note 2, at 987.

17. The phrase "declaration of sentiments" was also used as a memorialization of demands issuing from anti-slavery meetings and may represent one of the borrowings from that movement by early feminism. See, e.g., Am. Anti-Slavery Soc'y, Declaration of SEntiments and Constitution of THE AMERICAN ANTI-Slavery Society (Pa. Anti-Slavery Soc'y ed., 1861).

18. Siegel, She the People, supra note 2, at 987-88.

19. See Declaration of Sentiments (1848), reprinted in 1 History of Woman Suffrage 70-71 (Elizabeth Cady Stanton, Susan B. Anthony \& Matilda Joslyn Gage eds., 1881).

20. See, e.g., Aileen S. Kraditor, The Ideas of the Woman Suffrage Movement 1890 - 1920, at 46-50 (1965) (discussing the natural rights argument espoused by Elizabeth Cady Stanton). 
Part III examines the trajectory of arguments for women's rights that began prior to the Civil War and which emphasized liberty from the subordination imposed by marriage law. In the wake of that war, the movement reframed these arguments in terms of equality, drawing on the national discourse of equality that produced the Reconstruction Amendments. When the Supreme Court rejected a Fourteenth Amendment-based argument for suffrage, feminists directed their suffrage arguments to state legislatures. At the same time, in the same legislatures, advocates pursued the other half of a dual campaign for women's rights: eliminating the vestiges of coverture through adoption of the Married Women's Property Acts.

Part IV argues that by 1920, when the Nineteenth Amendment was adopted, a variety of legal, economic, and cultural factors had converged to produce at least formal acceptance of women as equal political actors. Efforts to achieve equality in marriage were ongoing, based on liberalization of state laws, eventually culminating in a new understanding of marriage as partnership that had developed in the joint suffrage and Married Women's Property Acts campaigns. The government's need for women to enter the non-domestic labor force during World War I undercut arguments that women belonged only in the home.

The transformation of marriage law did not occur, as the suffragists had hoped, in one dramatic moment but instead on an excruciatingly extended timeline. The piecemeal character of the process meant that debates about revisions of marriage law occurred over and over again, in state legislatures and in the courts interpreting the new statutes. Slowly but eventually, a fundamentally new understanding of the terms of marital governance emerged alongside the slow acceptance by the same legislatures of women's right to vote.

In Part V, which focuses on contemporary issues, I argue that an appreciation of the history and meaning of the Nineteenth Amendment would enrich the continuing resolution of challenges to restrictions on marriage, most recently the elimination of the exclusion of same-sex couples from access to that institution. Had the Supreme Court drawn on the lessons of the Nineteenth Amendment in Obergefell, it might have analyzed the issues before it with greater attention to the material, rather than the ethereal, aspects of marriage. One lesson of the full scope of the suffrage campaign - with its twin emphases on changing marriage and on securing the vote-is that marriage under law is a unique institution and one that, if the state elects to utilize and privilege it, must operate subject to the norms of a democracy composed of equal citizens rather than through the practices of caste and stratification.

Justice Kennedy's opinion for the Court in Obergefell began its first substantive section as follows: "Before addressing the principles and precedents that govern these cases, it is appropriate to note the history of the subject now before the Court." ${ }^{21}$ In the "history" that followed, the opinion posited marriage as an institution anchored in a sacred private realm that the law has adjusted to meet the 
changes of time, thus strengthening it. ${ }^{22}$ An understanding of marriage as a system for governing both individual rights and property, the keystone legal component of the movement that led to the Nineteenth Amendment, appears nowhere in the opinion.

Given the popularity of marriage, it may seem churlish to counter the Court's narrative of almost fairy-tale simplicity and happiness. Although the rate of Americans who marry has declined, most do marry ${ }^{23}$ and doubtlessly carry the hope, realized by many, that their union will profoundly enrich their lives. The argument of this Article is not that marriage today remains an intrinsically subordinating legal status for women, but that marriage as an institution must be consciously reinforced with values of freedom and pluralism to merit its enormous, continuing degree of protection by the state. I leave for another day the question of whether marriage should ever receive such privileged treatment under law.

This Article seeks to expand "the history of the subject" discussed by the Court in Obergefell and thus to reframe the relationship between liberty and equality that lies at the doctrinal core of any constitutional analysis of the structure of marriage. Essential to that task is an understanding of the history that is missing from the opinion - that of the Nineteenth Amendment. New approaches to liberty and a radical reinvention of the relationship between public and private arose from a social movement that sought to overthrow the legal structure of marriage as surely as the Framers sought to overthrow British control of the colonies. To properly adjudicate challenges to the structure of marriage as an institution of the state, one must understand the ideas, the popular discourse and the social meanings behind adoption of the Nineteenth Amendment.

Through this Article, I offer three contributions to the existing scholarship on the Nineteenth Amendment, constitutionalism and social movements. First, I argue that the Declaration of Sentiments has been seriously undervalued for its distinctive contributions to nineteenth century political philosophy, specifically for its contribution to shifts in the meaning of liberty after the Revolutionary War and before the Civil War. The Declaration articulated a collective framing for liberty, contradicting the conventional wisdom that the natural law philosophy of the Founders was limited to individualist claims of freeholders. It also directly challenged the gendered nature of the axiomatic principles-such as independence- underlying the natural law. Finally, the Declaration's construction of liberty as a collective claim of anti-subordination created a bridge between the Founders' vocabulary of liberty and attempts during the Reconstruction Era to embed equality of rights as an enforceable principle of constitutional law.

22. Id. at 2594-96.

23. Juliana Horowitz et al., Pew Res. Ctr., Marriage and Cohabitation in the U.S. 4 (2019), https://www.pewsocialtrends.org/2019/11/06/marriage-and-cohabitation-in-the-u-s/ [https://perma.cc/ KGK8-89H7]; Andy Kiersz, This Chart Shows the Exact Age When You're Most Likely to Get Married, BUS. INSIDER (Feb. 12, 2020, 4:13 PM), https://www.businessinsider.com/average-marriage-age-unitedstates-2019-2 [https://perma.cc/Q8LL-PV9C]. 
Second, I demonstrate the doctrinal and theoretical connections between the campaign to change the law of marriage that the suffragists undertook and the goals of the effort to legalize marriage for same-sex couples. Both sought to bring the internal and external dimensions of the law of marriage under the control of constitutional principles and norms. I argue that the demand to end the system of coverture and its legacies provides as strong a plumb line as the suffrage demand for connecting the founding of the American Women's Rights Movement in 1848 with the adoption of the 1920 Amendment. In turn, the Nineteenth Amendment provides a richer basis for the Court's decision in Obergefell than does the Court's rather thin reasoning.

Lastly, I identify the problems for constitutional interpretation posed by a text that-like the Nineteenth Amendment-emerged from a robust, divided and multi-generational social movement. Mixed motives drove enactment of the earliest Married Women's Property Acts, before the Women's Rights Movement emerged from the Seneca Falls convention. In later years, feminist proponents of marriage reform also deployed shifting and sometimes contradictory arguments regarding women's role in society. To the extent that there was a somewhat official reason for the eventual adoption of the Nineteenth Amendment, such as the explanation offered by President Wilson, it centered on a transactional relationship between granting the vote and the contributions that women had made to the national defense during World War I. The litigation campaign that culminated in Obergefell also deployed a mixture of justice-oriented and expedient arguments. Yet despite these complexities that ensue from real-life political engagement, I argue that intellectually honest understandings of the Nineteenth Amendment, the issue of same-sex marriage, and the relationship between the two, require recognition of the centrality to both of deep changes in the social as well as the legal meaning of marriage.

\section{EMANCIPATION}

For middle-class women coming of age in the antebellum United States, life in a rapidly industrializing society began to offer not only access to education and employment but also points of entry for political engagement. ${ }^{24}$ Most white men had been granted the franchise regardless of property ownership by the end of the $1820 \mathrm{~s}^{25}$ Social conventions discouraged women from speaking in public or even seeking signatures on petitions, ${ }^{26}$ but increasing numbers of women nonetheless sought participation in civic and economic life. ${ }^{27}$ One of the few venues for

24. SARa M. Evans, Born for Liberty: A History of WOMEn In AMERICA 60-61, 81-82 (1st Free Press Paperbacks ed. 1997).

25. Id. at 76 .

26. See Eleanor Flexner \& Ellen FitzPatrick, Century of Struggle: The Woman's Rights Movement in the United States 46-47 (1996).

27. In the first half of the nineteenth century, women living in urban areas in the United States formed hundreds of charitable organizations and, in the process, developed organizational skills and a sense of unfairness as to how the society treated women. BARBARA J. BERG, THE REMEMBERED GATE: ORIGINS OF AMERICAN FEMINISM 265-66 (1978). 
political discourse in which women were welcomed and even recruited was the anti-slavery movement formed primarily in the Northeast beginning in the early 1800 s. $^{28}$

In the anti-slavery movement, the women who later became the first leaders of the suffrage campaign acquired both organizing skills and intellectual grounding. ${ }^{29}$ From 1837 until Reconstruction, "the development of American feminism was inseparable from the unfolding of the antislavery drama." ${ }^{30}$ From abolitionism, women brought an egalitarian ideology and a theory of social change to bear on their own condition. ${ }^{31}$ Abolitionist writings began to reflect the crossover of the two movements, as exemplified by an 1838 abolitionist pamphlet recruiting women that "went far beyond women's role in the anti-slavery movement" and constituted "the first serious discussion of woman's rights by an American woman." 32 "By the early 1840s," many abolitionists "proved themselves committed to advocating woman's right as equal rights." 33

Suffragists believed the vote to be not only its own goal, but also the means to reach a different goal of at least equal importance: ending the oppression embodied in the regulatory structures of the law of domestic relations, especially coverture. Under the law of coverture, absent exceptional circumstances, ${ }^{34}$ marriage stripped women of their rights to control their own property or wages, make contracts, bring suit, assert independent rights to parent children, and make any of a long list of decisions about where and how they lived. ${ }^{35}$ Exit through divorce was minimal until the last decades of the nineteenth century. ${ }^{36}$ Combining demands for voting and for emancipation from the bonds of the legal construct of marriage, if not from their own marriages, created an eminently logical political program: "marriage and the state were both understood to be forms of governance." 37

The strictest forms of coverture first began to give way early in the Republic, beginning with modest liberalization of divorce law when the Revolutionary War ended and states could take actions that British colonial authority had

28. SuZanne M. Marilley, Woman Suffrage and the Origins of Liberal Feminism in the UnITED STATES, 1820-1920, at 20-22, 27 (1996); see also FleXNER \& FitZPATRICK, supra note 26, at 42.

29. See DuBoIs, supra note 14 , at 22; MARILLEY, supra note 28 , at 27-28, 34 .

30. DuBoIs, supra note 14 , at 31.

31. Id. at $32,36-38$.

32. FLEXNER \& FITZPATRICK, supra note 26, at 44, 348 n.19.

33. MARILLEY, supra note 28 , at 43.

34. Nineteenth century equity courts occasionally provided protective trusts to safeguard the estates of married women. LeO KANOWITZ, WOMEN AND THE LAW: THE UnFINISHEd ReVOLUTION 38-40 (1969). See Albie Sachs \& Joan Hoff Wilson, Sexism and the Law: A Study of Male Beliefs AND Legal Bias in Britain And the United StATes 77-79 (1978). Customary law also developed in some commercial contexts such as whaling, in which wives needed to make family and business decisions independently while husbands were gone for long periods. Mary L. Heen, Agency: Married Women Traders of Nantucket, 1765-1865, 21 GEO. J. GENDER \& L. 35, 45-49 (2019).

35. See CotT, supra note 5, at 11-12; Hendrik Hartog, MAN AND WiFE IN AMERICA: A History 99-100 (2000); KANOWITZ, supra note 34, at 35-36.

36. DEGLER, supra note 10, at 165-66.

37. Сотт, supra note 5, at 12. 
prohibited. ${ }^{38}$ Efforts to enact married women's property acts began soon after, in the first half of the nineteenth century. ${ }^{39}$ Legislators concerned with mitigating the extremes of coverture law acted in response to the concerns of multiple groups, including pre-suffragist reformers, seeking fairness for women; ${ }^{40}$ creditors seeking repayment of debts incurred by women when they were single that became difficult or impossible to collect after they married; ${ }^{41}$ and fathers wishing to insulate property that would pass to their daughters from the opportunism of feckless husbands. ${ }^{42}$

Coverture was more than a set of laws, however-it had social and political meanings as well as legal consequences. Socially, its acceptability ran hand-inglove with the cultural norms associated with a philosophy of separate spheres, in which women were believed best fit for domestic responsibilities. ${ }^{43}$ Politically, it provided a rationale for denial of the vote for women, on the ground that the dependence of wives on their husbands for economic support and legal capacity justified the husband's role as representation of their interests in political life. ${ }^{44}$ As a result, understanding women's citizenship in the United States "requires centering on the institution of marriage." 45

The overlap of culture with politics produced a justification for denying the vote not only to married women-as to whom the legal fiction of representation could at least apply — but also to unmarried women, who were presumed to be anticipating marriage or dismissed as "exceptions to the general rule." ${ }^{46}$ "[C]overture ... transformed women into wives," ${ }^{, 77}$ for purposes of the legal system so thoroughly that its reach extended even to single women. The ideology of coverture conflated gender and marriage. The overall effect of such a transformation was that the legal system constructed marriage as the equivalent of a subsidiary political institution. Marriage became both an instrument and a technology of power.

38. Linda K. Kerber, Women of the Republic: Intellect \& Ideology in Revolutionary AMERICA 10, 159-60 (1980).

39. First was Arkansas in 1835, followed by Mississippi in 1839, followed by New York in 1848. Richard H. Chused, Married Women's Property Law: 1800-1850, 71 Geo. L.J. 1359, 1359, 1398 \& n.199 (1983).

40. The New York Times editorialized in favor of reform as "legal protection and fair play" for women, distinguishing those concerns from those of "extreme advocates of Women's Rights." DuBors, supra note 14, at 46 (citing Property of Married Women, N.Y. Times, Apr. 8, 1859, at 4).

41. Chused, supra note 39, at 1402-04; Reva B. Siegel, The Modernization of Marital Status Law: Adjudicating Wives' Rights to Earnings, 1860-1930, 82 GEO. L.J. 2127, 2135-36 (1994).

42. Chused, supra note 39, at 1372; Siegel, supra note 41, at 2135-36, 2136 n.28.

43. See DEGLER, supra note 10, at 26. See generally NANCY F. COTT, THE BONDS OF WOMANHOOD: “Woman's SPHERE" IN NEW ENGLAND 1780-1835 (2d ed. 1997). Although the culture of separate spheres opened paths for women's influence in domestic and religious contexts, it simultaneously "barricaded all others." Id. at 200-01.

44. Siegel, She the People, supra note 2, at 981-87; see also HARToG, supra note 35, at 106.

45. Nancy F. Cott, Marriage and Women's Citizenship in the United States, 1830-1934, 103 AM. Hist. Rev. 1440, 1442 (1998).

46. Bradwell v. Illinois, 83 U.S. (16 Wall.) 130, 141 (1872).

47. HARTOG, supra note 35, at 135. 
What the suffragists saw in the lives of middle-class women like themselves was a two-sided trap constructed by and through law: civil erasure upon entering marriage enacted through the doctrine of coverture, combined with exclusion from most paid employment - the only means other than marital dependency to secure the necessities of life. ${ }^{48}$ The legal incidents of marriage blocked women's ability to exit the domestic sphere ${ }^{49}$ and operated in tandem with practices that restricted entry to the labor market. ${ }^{50}$

A second dimension of the power of coverture lay in the quasi-sovereignty of its jurisdictional authority. Marriage generated not just gender-defined devices of subordination but also a realm of private governance-by the husband-into which courts seldom ventured so long as the marriage was ongoing. ${ }^{51}$ This vestige of coverture endured even after decades of reform had chipped away at property and contract laws. ${ }^{52}$

\section{The Charter of American Feminism}

American feminism's foundational text, the Declaration of Sentiments adopted at the 1848 Seneca Falls convention, framed the movement's goals as broadly and deeply challenging to male supremacy. ${ }^{53}$ It prioritized two goals: winning the vote, and eliminating male prerogatives in the law of marriage. ${ }^{54}$ The attack on coverture "was no timid sister" of the effort to win the vote. ${ }^{55}$ Suffragists also believed that enfranchising women would force adoption of laws eliminating

48. Traditionally, marriage law has been "fashioned to a considerable extent with the employability of women in mind." KANOWITZ, supra note 34, at 98.

49. Elizabeth Cady Stanton and other suffrage leaders advocated legal changes that would make divorce easier. DEGLER, supra note 10, at 175. Stanton also argued that women's power within marriage would be enhanced by having stronger rights to her own property and earnings. KRADITOR, supra note 20 , at 47 .

50. Susan B. Anthony also linked suffrage to economic empowerment, saying in 1869 that suffrage "will change the pecuniary position of woman; it will place her where she can earn her own bread. . . . She will not then be driven to such employments only as man chooses for her." Susan B. Anthony, Remarks at the May Anniversaries of the American Equal Rights Association in N.Y. and Brook. (May 12-14, 1869), in 2 History of Woman SufFrage 378, 383 (Elizabeth Cady Stanton, Susan B. Anthony \& Matilda Joslyn Gage eds., 1881).

51. The most commonly cited reason was the need to preserve "domestic harmony." Note, Litigation Between Husband and Wife, 79 HARV. L. REv. 1650, 1650 (1966). Courts also reasoned that judicial fora were not the proper venues for intra-family debates. $I d$. at 1655 . One court declared that a "wide latitude of discretion must be allowed" to husbands for decisions about expenses. Id. at 1657 (quoting Pattberg v. Pattberg, 120 A. 790, 791 (N.J. Ch. 1923)).

52. See, e.g., Lon L. Fuller, The Forms and Limits of Adjudication, 92 HARV. L. REV. 353, 370-71 (1978) (arguing that "[a]djudication is not a proper form of social ordering" in some cases, such as those involving agreements between husband and wife on domestic matters).

53. Elizabeth Cady Stanton et al., Declaration of Sentiments and Resolutions - Seneca FALLS (1848), https://liberalarts.utexas.edu/coretexts/_files/resources/texts/1848DeclarationofSentiments. pdf $[$ https://perma.cc/LP4Q-K8UB].

54. See id.

55. Reva B. Siegel, Home as Work: The First Woman's Rights Claims Concerning Wives' Household Labor, 1850-1880, 103 YALE L.J. 1073, 1078 (1994). 
coverture. ${ }^{56}$ The tendency today to associate Seneca Falls only with the former overlooks what many feminists at the time thought was the more important issue. $^{57}$

\section{A. THE DECLARATION}

The idea to call a convention on the rights of women grew directly from the work of Elizabeth Cady Stanton and others to persuade the New York legislature to enact a bill granting married women more power over their own property. ${ }^{58}$ Their petition to the legislature had invoked "your Declaration of Independence" and argued that women, having never consented to the laws under which they were governed, should not be bound by them. ${ }^{59}$ Stanton wanted to do more. Triggered by her advocacy of the property reform bill, her memory of the exclusion of women from an anti-slavery conference in London and her own experiences as a wife and mother, Stanton led the group in calling for a convention to discuss the "rights of woman."

Stanton used the Declaration of Independence as her primary model, in a deliberate attempt to signal the radicalism of the group's demands. ${ }^{61}$ As a result, the language and structure of the Declaration of Sentiments closely parallels that of the Declaration of Independence. ${ }^{62}$ The Declaration of Sentiments stressed two themes..$^{63}$ One was that the denial of voting rights to women exposed the nation's hypocrisy in claiming to be based on the "consent of the governed." ${ }^{64}$ The other, placed second but given more space in the text, was that men's domination of

56. " $[\mathrm{I}] \mathrm{t}$ will be woman's fault, if, the ballot once in her hand, all the barbarous, demoralizing, and unequal laws, relating to marriage and property, do not speedily vanish from the statute-book . . .." Wendell Phillips, on behalf of the Business Committee, Resolutions at the Proceedings of the Woman's Rights Convention, Held at Worcester, October 15th and 16th, 1851 (transcript of address and resolutions available at the Library of Congress), https://tile.loc.gov/storage-services/service/rbc/ rbnawsa/n8287/n8287.pdf https://www.loc.gov/resource/rbnawsa.n8287/?sp=1\&st=gallery [https:// perma.cc/43UM-5YYA https://perma.cc/FU8F-TGWB].

57. See DEGLER, supra note 10, at 329; see also Thomas, supra note 2, at 11-12.

58. EVANS, supra note 24, at 93-94.

59. Id. at 94 .

60. FLEXNER \& FITZPATRICK, supra note 26, at 69.

61. KRADITOR, supra note 20, at 1; Siegel, She the People, supra note 2, at 987-88. Stanton wrote: "The reports of Peace, Temperance, and Anti-Slavery conventions were examined, but all alike seemed too tame and pacific for the inauguration of a rebellion such as the world had never before seen." Elizabeth Cady Stanton, Planning the Seneca Falls Convention: 1848, in KATHRYN KISH SKLAR, Women's Rights EMERGes Within the Antislavery Movement 1830-1870: A Brief History with DOCUMENTS 170, 171 (2000).

62. Like the latter, the former comprises "a classical oration in five parts." Howard Mumford Jones, The Declaration of Independence: A Critique, in THE DECLARATION OF INDEPENDENCE: Two Essays 3 , 3 (1976). It begins with a brief paragraph adopting the goal of self-sovereignty; continues with a longer paragraph stating general principles; enumerates the grievances that require redress; and concludes with resolutions and a final statement of the signers' commitment to the effort. See id.

63. There was consensus for the sections relating to reform of marriage and other laws; Stanton also included the right of women to vote despite less than unanimous agreement. MARILLEY, supra note 28, at $50-51$.

64. Declaration of Sentiments (1848), supra note 19, at 70-71. 
women, described most frequently in the enumerations section as occurring in the context of family law, constituted a form of tyranny. ${ }^{65}$

The opening general principles section stressed the end of a colonization of women's lives. ${ }^{66}$ Of the fifteen grievances alleged to specify "this entire disenfranchisement," the Declaration of Sentiments began with four that assert the right to vote and five that describe the injustices of the law of marriage and divorce. ${ }^{67}$ The remaining six address employment, education, the ministry, a double standard for morals, and what we would call today emotional abuse. ${ }^{68}$

The parallel structures of the Declaration of Sentiments and the Declaration of Independence illustrate more than a linguistic coincidence or historical echo. Fundamentally, both attacked tyranny. The key difference grew from the contrast between the experiences of the two respective groups of drafters. The white male property owners who signed the Declaration of Independence were not seeking the right to vote per se, which they had exercised with regard to local matters in colonial assemblies, but instead the creation of a new sovereign state in which their voting was assumed. The women of 1848 were not seeking a new sovereign state, but to jettison an old one- the kingdom built on coverture-and to enter an existing one, through voting. Thus, the Declaration of Sentiments resonates with the themes of collective autonomy for a class of persons and the right to inclusion of the class in the processes and structures of governance.

\section{B. COLLECTIVE LIBERTY AND THE BRIDGE TO EQUALITY}

Traditionally understood, liberty presents a quintessentially individualist claim. The Declaration of Independence reflected the belief that an implicit

65. Linda Kerber described "the first, and most firmly voiced complaints" in the Declaration as "the denial of the suffrage, the economic and physical subordination of married women to their husbands, the vulnerability of women in divorce cases. These were the most substantial and serious of the women's resentments." Linda K. Kerber, From the Declaration of Independence to the Declaration of Sentiments: The Legal Status of Women in the Early Republic 1776-1848, 6 Hum. RTS. 115, 116 (1977).

66. In its second paragraph stating general principles, the Declaration of Independence states:

[W]hen a long train of abuses and usurpations, pursuing invariably the same object, evinces a design to reduce them to absolute despotism .... Such has been the patient sufferance of these colonies .... The history of the present King of Great Britain is a history of repeated injuries and usurpations, all having in direct object the establishment of an absolute tyranny over these states.

The Declaration of IndePEndence para. 2 (U.S. 1776) (italics added). The second paragraph of the Declaration of Sentiments states:

[W]hen a long train of abuses and usurpations, pursuing invariably the same object, evinces a design to reduce them under absolute despotism .... Such has been the patient sufferance of the women....

The history of mankind is a history of repeated injuries and usurpations on the part of man toward woman, having in direct object the establishment of an absolute tyranny over her.

DeClaration OF SENTIMENTS (1848), supra note 19, at 70.

67. See id. at 70-71.

68. See id. at 71 . 
component of a claim for liberty as an inalienable natural right is the assertion of an equal entitlement by rights-bearing subjects to freedom from oppression and appropriation by the state. ${ }^{69}$ The colonial elites in protest against the divine right of kings asserted their prerogative for self-government, certain in their belief that God created them as equals to the white, male property owners in England who ruled them.

Even today, in the jurisprudence of natural rights, liberty holds a central and fundamental position: it is posited as the source of both property and freedom and of the linkage between the two. Liberty is considered to be prepolitical, the core of a philosophy that privileges the survival of fundamental personal freedoms that remain shielded from state intrusion even after the individual gives up other prerogatives in order to obtain the benefits of mutual protection that are provided by government. ${ }^{70} \mathrm{It}$ is on this basis that libertarians claim the 1776 Declaration of Independence as evidence of a congenial original understanding that prioritizes individualist rights over mutuality. ${ }^{71}$

Against this background, the Declaration of Sentiments stands in underappreciated contrast, a foundational document in American constitutionalism. The women's demand for collective liberty was new, not simply a repeat of the individualist understanding of liberty upon which the Declaration of Independence was based. The idea of a collective liberty right arose from a position of class-wide exclusion from political rights, as voiced by black Americans and women, rather than from one of less power than others of comparable economic and social standing that characterized the signers of the Declaration of Independence and the Framers of the Constitution. ${ }^{72}$ The breakthrough of the Declaration of Sentiments was its claim for liberty not just as an individual right applicable as much to property as to freedom, but also as one made in the voice of anti-subordination.

More specifically, the Declaration called out the ways in which the law and norms of coverture destroyed the purported universalism of natural law philosophy. The limiting principle as to the scope of liberty, inherited from English

69. The most influential source for their beliefs was John Locke, author of The Second Treatise of Government. See Morton White, The Philosophy of the American Revolution 11 (1978).

70. Randy E. Barnett, The Declaration of Independence and the American Theory of Government: “First Come Rights, and Then Comes Government," 42 HARV. J.L. \& PuB. POL'Y 23, 25-26 (2019).

71. Id. at 25 ("They are not group rights. They are not collective rights. They are the individual rights of We the People, each and every one.").

72. As historian Ellen DuBois wrote with regard to the tradition of women's rights:

[It] treats rights . . . as something to be won and exercised collectively rather than individually; as the object of political struggle . . . ; as that which government affirmatively establishes rather than negatively shields; and above all as that which has greatest meaning not to the powerful, who already enjoy their entitlements, but to the powerless, who have yet to have their full place in society recognized.

Ellen Carol DuBois, Taking the Law into Our Own Hands: Bradwell, Minor, and Suffrage Militance in the 1870s, in One Woman, One Vote: Rediscovering the Woman Suffrage Movement 81, 83 (Marjorie Spruill Wheeler ed., 1995). 
common law, was sic utere tuo ut alienum non laedas, or the maxim that one's liberty extends only to the point that it does not harm another. ${ }^{73}$ Although portions of Locke's work treat women as separate political subjects, he nonetheless describes women only in the context of their relationships to others. ${ }^{74}$ A woman defined as wife and especially mother could not be a free actor without possibly harming her children, a deep cultural trope that persists in the legal powers granted to states to regulate pregnant women. Thus, women could be per se barred from the complete natural rights understanding of liberty. Additionally, Locke's philosophy predicated the right to vote on independence, symbolized by ownership of property. ${ }^{75}$ Coverture enforced dependence, and financial dependence signaled the inability to vote as a free agent.

Lastly, the Declaration of Sentiments provided a rhetorical bridge to a fuller belief in equality that, for its most committed drafters, did extend to "all men and women." The underlying political theory in the Declaration of Sentiments came from the anti-slavery movement, expanded to capture the social status of women. As stated in the call for the First National Women's Rights convention after Seneca Falls:

In the relation of marriage [woman] has been ... enslaved in all that concerns her personal and pecuniary rights; and even in widowhood and single life, she is oppressed [in ways that] mark the condition of a disabled caste. ${ }^{76}$

The language of equality was not absent from the Declaration of Sentiments, as exemplified by how the recitation section of the 1776 document of "self-evident truths" was altered in 1848 to begin: "that all men and women are created equal."77 But equality as we understand it today—not just as an inborn quality of each human but as a binding principle applying to all forms of political and social life — was not the dominant understanding at that time. ${ }^{78}$ As it was used in the Declaration of Independence, equality was understood to be an aspirational term, such that it could coexist with slavery. ${ }^{79}$

73. Elmer E. Smead, Sic Utere Tuo Ut Alienum Non Laedas: A Basis of the State Police Power, 21 CORNELl L.Q. 276, 276, 278 (1936).

74. See KERBER, supra note 38, at 17-18, 27.

75. See WhiTE, supra note 69, at 259-60 (noting that Alexander "Hamilton's willingness to accept the idea of property qualifications for voting" were based on "Lockean moral philosophy").

76. Siegel, supra note 55, at 1100 (citation omitted).

77. StANTON ET AL., supra note 53 (emphasis added). In addition, the penultimate section of resolutions contains additional references specifically to equality, for example, "that woman is man's equal—was intended to be so by the Creator" and "[t]hat the equality of human rights results necessarily from the fact of the identity of the race in capabilities and responsibilities." Id.

78. The distinction is reflected in a resolution adopted by an 1851 women's convention declaring " $[t]$ hat we do not feel called upon to assert or establish the equality of the sexes .... [N]atural and political justice, and the axioms of English and American liberty, alike determine that rights and burdens - taxation and representation-should be co-extensive ...." Resolutions Passed at a Woman's Rights Convention (1851), as reprinted in Up FROM THE PEDESTAL 220, 221 (Aileen S. Kraditor ed., 1968).

79. See Alexandeer Tsesis, For Liberty and Equality: The Life and Times of the DECLARATION OF INDEPENDENCE 20 (2012). 


\section{SOCIAL MEANINGS}

Various political actors wove themes of equality into popular interpretation of the Declaration of Independence, retroactively making it into an anthem that reaches beyond the horizons envisioned by those who wrote it. Historian Pauline Maier has described how the Declaration of Independence was remade into a "sacred text," one that is understood to stand for equality even though it "was, in fact, a peculiar document to be cited by those who championed the cause of equality." Most Americans believe that the "created equal" phrase from the Declaration of Independence is part of the Constitution. ${ }^{81}$ Political philosopher Danielle Allen has argued that, contrary to conventional wisdom, the primary message and public meaning of the Declaration of Independence today is not liberty but equality. ${ }^{82}$

Through the Declaration of Sentiments, the suffragists expanded the meanings of liberty and equality from what was in the Declaration of Independence in a unique way. Unlike the Declaration of Independence, the Declaration of Sentiments identified two governance structures at issue: the official public state, and the state-enforced rules of the purportedly private ream of marriage. The meanings created by the early suffragists - collective liberty from domestic tyranny and equality in the purportedly private sphere-provided an understanding of liberty and equality as constructed by and through the operations of gender. Just as the Declaration of Independence inspired and remains associated with the equality guarantee of the Fourteenth Amendment, the Declaration of Sentiments merits inclusion among the nation's foundational texts as the inspiration and engine for the Nineteenth Amendment.

\section{A Dual CAmpaign}

Women's rights advocates built on the analysis and political theory derived from the Declaration of Sentiments to create a social movement that led to the Nineteenth Amendment. I will analyze the movement in three stages that mark the development of the underlying legal arguments. From Seneca Falls through the Civil War, the campaign focused on ending coverture. The effort to reform marriage law had begun before 1848, but women's rights advocates effectively took over its leadership through their organizing after Seneca Falls. ${ }^{83}$ Even during the war years, Elizabeth Cady Stanton continued her focus on family law issues during the lyceum circuit speaking tours she did from 1861 to $1872 .{ }^{84}$

80. Pauline Maier, American SCripture: Making the Declaration of IndePendence 175, 192 (1997). Maier goes on to explain: "Not only did its reference to men's equal creation concern people in a state of nature before government was established, but the document's original function was to end the previous regime, not to lay down principles to guide and limit its successor." Id. at 192.

81. Katie R. Eyer, The Declaration of Independence as Bellwether, 89 S. CAL. L. REV. 427, 428 (2016).

82. See Danielle Allen, Our Declaration: A Reading of the Declaration of Independence IN DEFENSE OF EQUALITY 108, 275-77 (2014).

83. Siegel, supra note 41 , at 2137.

84. Thomas, supra note 2 , at 12. 
In the second stage, after the Civil War ended and the Reconstruction Amendments failed to provide suffrage for women, women's rights advocates sought the vote through the courts, relying on the Fourteenth Amendment. Although the second phase ended when the Supreme Court rejected that argument in Minor $v$. Hapersett,${ }^{85}$ the movement's reliance on a discourse of equality continued. A women's declaration issued in 1876, during the centennial celebrations of the Constitution, illustrated the extent to which the constitutional arguments made in Minor had realigned the rationale for women's suffrage into one based on legal doctrine and a more individualized sense of rights claims.

The third stage stretched from 1876 until the adoption of the Nineteenth Amendment in 1920. Women's rights advocates returned to the arenas of legislation and elections, pursuing both suffrage and marriage reform, with the singleissue argument for the former goal taking priority over the latter, which involved multiple and complex issues of family law.

During the entire period, however, the political and social meanings of the two parts of this dual campaign remain fused in the debates over women's legal and social independence.

\section{A. FROM SENECA FALLS TO FORT SUMTER}

Agitation for additional married women's property acts increased dramatically in the decade leading up to the Civil War because of the women's rights organizing that followed Seneca Falls. ${ }^{86}$ At the national and local women's rights conventions held throughout the 1850s, "participants' resentment at wives' subordination within marriage" was often voiced more frequently than the demand for suffrage ${ }^{87}$ Elimination of " "all the barbarous, demoralizing, and unequal laws related to marriage and property' [was] their primary goal." 88 References to the legal rights, or lack thereof, of married women appear repeatedly in the resolutions adopted by these conventions. ${ }^{89}$ The women's "[c]onventions put the issues of women's rights into the press and before the public eye almost continuously." $" 90$

In addition, between 1845 and 1860, almost every state adopted a new constitution. ${ }^{91}$ Provisions to change the law of marital property arose repeatedly at the

85. 88 U.S. (21 Wall.) 162, 163, 178 (1875).

86. See Thomas, supra note 2 , at 3 .

87. CotT, supra note 5, at 64.

88. MARILlEY supra note 28, at 53; see also Thomas, supra note 2, at 11.

89. See, e.g., Address to the Second National Convention in Worcester, reprinted in 1 HISTORY OF WOMAN SUFFRAGE, supra note 19, at 238 (statement of Ernestine Rose) ("In the laws of the land she has no rights; in government she has no voice. . . . From the cradle to the grave she is subject to the power and control of man. ... At marriage, she loses her entire identity, and her being is said to have become merged in her husband."); Address to the Syracuse National Convention, September 8, 9, and 10, 1852, reprinted in 1 HISTORY OF WOMAN SUFFRAGE, supra note 19, at 517-30.

90. The Concise History of Woman Suffrage 89 (Mari Jo Buhle \& Paul Buhle eds., 2005); see also MARILLEY, supra note 28, at 54-55, 62-64.

91. HARTOG, supra note 35, at 110. 
conventions where constitutional changes were drafted..$^{92}$ In addition to New York, especially intense debates occurred in Wisconsin, California, and Indiana, in which "men declared that these were the most important, most fundamental measures considered within the draft constitutions." 93 Women also scheduled separate conventions in tandem with the state amendment process in order to demand "just laws for married women" and suffrage. ${ }^{94}$

Together, the two sets of conventions ensured that debates over changes to the law of marriage became part of the political landscape at midcentury. Although women's rights concerns did not initiate the pre-Seneca Falls property law amendments, they came to dominate or at least shape legislative enactments in an impressively short period of time. In three major states-New York, Ohio, and Massachusetts-women's lobbyists drove changes that became models for other states. ${ }^{95}$ By 1861, the majority of states had adopted some form of protection of married women's property, motivated by a mix of feminist and unrelated concerns. ${ }^{96}$ Congress, too, had taken note; it addressed the issue of married women's property ownership in the legislation establishing the terms for land grants in western territories such as Oregon. ${ }^{97}$

By the onset of the Civil War, several realities about the politics of marriagelaw reform had emerged that would continue to mold the social meanings of that branch of feminism well into the next century. As time went on, women's rights advocacy came to the forefront of the arguments in favor of revising marriage law, although mixed motives endured. But feminist demands shifted. Women began by seeking relatively modest changes (at least by today's standards) related mostly to maintaining separate ownership of property and the independent capacity to contract, as well as joint guardianship of children. Prewar successes led to what turned out to be premature celebration. ${ }^{98}$ As the early issues were addressed in the most progressive states, women pressed others, seeking new rights on issues such as control of their own wages, inheritance law, and the

92. Id. at $110-11$.

93. Id. at 111 .

94. Mrs. M. E. J. Gage, Women's Rights Meeting in a Barn-“John's Convention.," reprinted in 1 HisTORY OF WOMAN SUFFraGE, supra note 19, at 117.

95. Elizabeth Bowle Warbasse, The Changing Legal Rights of Married Women, 1800-1861, at 26471, 274 (Feb. 1960) (Ph.D dissertation, Radcliffe College).

96. See supra text accompanying notes $39-42$.

97. Richard H. Chused, Late Nineteenth Century Married Women's Property Law: Reception of Early Married Women's Property Acts by Courts and Legislatures, 29 J. AM. J. LeGAL Hist. 3, 6 (1985).

98. For example, in 1856, Lucy Stone hailed the impact of women's rights advocates in the first phase of marriage-reform laws:

Never before has any reformatory movement gained so much in so short a time. ...

Now almost every Northern State has more or less modified its laws. . . .

Ohio, Illinois, and Indiana have also very materially modified their laws. And Wisconsin . . .

has granted almost all that has been asked except the right of suffrage.

Lucy Stone, Address to Seventh National Woman's Rights Convention (Nov. 25-26, 1856), reprinted in 1 History OF Woman SuFFrage, supra note 19, at 632. 
capacity to bring suit against their husbands. ${ }^{99}$ Finally, the law reform effort was complicated by geographic variance: even before the Civil War, a pattern developed of much greater hesitancy to abridge husbands' prerogatives in southern, rather than northern, states. ${ }^{100}$

Even apart from whether granting the vote to women or ending the vestiges of coverture may have seemed more radical and thus less politically feasible in any specific context, these structural factors exacerbated the difficulty of changing the law of family relations. During any given year, different state legislatures were considering bills raising different specific questions. A binding nationwide resolution was achievable only through the Supreme Court, by Congress, or by constitutional amendment. But the governance of marriage and family was a creature of state law, the discourse of which would not be constitutionalized until much later.

\section{B. THE RECONSTRUCTION AMENDMENTS}

In the wake of the Civil War, Congress transformed the national understanding of liberty and equality through adoption of the Thirteenth and Fourteenth Amendments, but deliberately framed both in ways that rejected considerations of women's legal status. ${ }^{101}$ In debating the Fifteenth Amendment, Congress focused on to whom the vote should be guaranteed and provided its protection against denial or abridgement only on account of "race, color or previous condition of servitude." 102 Exclusion from the democratization of the franchise compelled women's rights advocates to focus on the vote. They turned to the newly adopted Privileges and Immunities Clause and, more generally, the discourse of equality. In this era, the master proxy for racial equality - the issue dominating national politics - became suffrage, a dynamic which helped move suffrage to the top of women's rights political agenda.

With Virginia Minor as plaintiff and her husband Francis as lawyer and costrategist, suffrage advocates attempted to secure the right to vote as one of the "privileges and immunities" of citizenship and thus protected from infringement by Section 1 of the Fourteenth Amendment. Their 1873 brief to the Supreme Court in Minor v. Happersett ${ }^{103}$ marked a major transition in the framing of women's rights. Reliance on the Fourteenth Amendment shifted the priority away from the anti-tyranny arguments in the 1848 Declaration, directed at the

99. Warbasse, supra note 95, at 271, 273; Siegel, supra note 41, at 2138-39.

100. Warbasse, supra note 95 , at 283-84.

101. Congress rejected an early version of the Thirteenth Amendment which had provided that "no person can hold another as a slave," from concern that it might apply to women as a class. COTT, supra note 5, at 80. Women's rights advocates objected to insertion of the word "male" into the Fourteenth Amendment, to no avail. EvANS, supra note 24, at 122. One consequence of the end of slavery-ironic as a marker of equality — was the extension of the right to marry to formerly enslaved persons. Formerly enslaved persons welcomed the removal of this badge of slavery, but marriage law served regulatory as well as beneficial ends. KAtherine Franke, Wedlocked: The Perils of MARriage Equality 49-50, $117-43,163-83$ (2015).

102. See U.S. Const. art. XV.

103. 88 U.S. (21 Wall.) 162 (1875). 
restrictions of marriage law, and toward the newly constitutional ground of equality. Advocates highlighted the absence of voting rights for women by contrast to the Fifteenth Amendment. Like all briefs, Minor's offered the Court a variety of rationales, including some that sounded in collective liberty. ${ }^{104}$ Overall, though, it signaled the adoption by women's rights advocates of more legalistic and textual arguments. ${ }^{105}$

The Supreme Court rejected the Minors' claims, holding that although women were citizens (as were children, for example), the function of Section 1 was only to protect the existing privileges and immunities of that status, not to create new ones. ${ }^{106}$ The Court found no indication that the Amendment was intended to overturn the virtually universal practice of limiting the franchise to men. ${ }^{107}$ Thus, the states had the authority through their police powers to determine whether women were entitled to vote.

The Minor decision was of a piece with a broad retrenchment after the end of Reconstruction. For women, the first sign came in Bradwell v. State, in which the Court ruled that Illinois had discretion to deny Myra Bradwell admission to the bar. ${ }^{108}$ The holding was based on the Court's ruling that the Privileges and Immunities Clause did not protect one's choice of profession, but the most famous passage came in Justice Bradley's concurrence in which he relied on "a constitution of the family" as controlling the domestic sphere to which women properly were confined. ${ }^{109}$ The Court also reneged more broadly on the promise of the Reconstruction Amendments, upholding state power to enact Jim Crow "separate but equal" laws; ${ }^{110}$ invalidating the first federal Civil Rights Act as improperly extending to nongovernmental actions; ${ }^{111}$ and stripping the Privileges and Immunities Clause of meaning or power. ${ }^{112}$

The Court's rulings anticipated the elevation of laissez faire as a dominant principle in constitutional adjudication and as a unifying theme of American jurisprudence in the post-Reconstruction era. As Frances Olsen pointed out:

104. The brief asked the Court "to consider what it is to be disenfranchised; not this plaintiff only, but an entire class of people ... . Her disfranchised condition is a badge of servitude." Plaintiff's Brief and Argument, Minor v. Happersett, 88 U.S. (21 Wall.) 162 (1875), reprinted in UP FROM THE PEDESTAL, supra note 78 , at 241.

105. The brief included arguments that denial of the vote amounted to a bill of attainder prohibited in Article I, Section 9, and sought relief under the Ninth Amendment of rights reserved to the people. Id. at 236, 241.

106. Minor, 88 U.S. (21 Wall.) at 171-72.

107. Id. at $173-74$.

108. 83 U.S. (16 Wall.) 130, 140, 142 (1873).

109. Id. at 141 .

110. See Plessy v. Ferguson, 163 U.S. 537, 551-52 (1896), overruled by Brown v. Bd. of Educ., 347 U.S. 483 (1954).

111. See The Civil Rights Cases, 109 U.S. 3, 25-26 (1883).

112. See The Slaughter-House Cases, 83 U.S. (16 Wall.) 36, 82-83 (1872). 
The classic laissez-faire arguments against state regulation of the free market find a striking parallel in the arguments against state interference with the private family.

$\cdots$

Actual inequality and domination in the family ... are represented as private matters that the state did not bring about .... ${ }^{113}$

The logic of laissez faire depended on and perpetuated the deference paid by the legal system to marriage as a quasi-sovereign form of governance, into which the official state would not intrude absent drains on the public fisc or visible violations of moral norms. ${ }^{114}$

With regard to family, the private sphere was private in two senses: it was immune to public regulation absent extreme circumstances, and it was roughly equivalent to private property. "It 'belonged' to the husband. And, for a wife, being married meant being subject to a husband within his private domain." 115

As emphasized by the Court in both Bradwell ${ }^{116}$ and Minor, ${ }^{117}$ to the extent that government ventured into the regulation of the intertwined issues related to women's status and family law, it was to occur by state-level as distinct from federal action. Like the states' rights discourse that contributed to the reinstatement of white supremacist government through Jim Crow laws, the privileging of state-level control of the woman/wife conflation implicitly denied the importance of the national and constitutional values through which women claimed full citizenship rights. Instead, the discourse of domesticity merged with that of states' rights to dominate judicial consideration of these issues. Doctrinally and immediately, the ruling in Minor barred any hope of challenging the laws of coverture under the Fourteenth Amendment.

\section{DOUBLING DOWN ON LIBERAL RIGHTS}

The defeat in Minor ended the suffragists' attempts to win the vote through judicial interpretation of the Reconstruction Amendments, but they continued to deploy the discourse of equality for women. Having established women's suffrage as a national political issue that would not recede from the national stage in law or politics, either in Congress or in the Supreme Court, they carried forward and prioritized arguments now grounded in the Constitution but presented them in the arenas of state-level lawmaking and public opinion. One result was the increasing reliance on more individualist liberal rights formulations of their claims.

113. Frances E. Olsen, The Family and the Market: A Study of Ideology and Legal Reform, 96 HARV. L. REV. 1497, 1502, 1506 (1983).

114. See HARTOG, supra note 35 , at 25 .

115. Id. at 108 .

116. 83 U.S. (16 Wall.) at 139.

117. 88 U.S. (21 Wall.) 162, 170-72 (1875). 
The change was evident at a celebration of the nation's centennial three years after Minor, when Susan B. Anthony interrupted the event and read the Declaration of Rights of the Women of the United States, which drew on a discourse of legal rights grounded in the Constitution. ${ }^{118}$ Both the Declaration of Sentiments and the 1876 Declaration attacked unfair laws, but whereas the 1848 Declaration had framed the target as male "establishment of an absolute tyranny," 119 akin to British colonial rule, the 1876 Declaration framed its objections as based on specific individual rights. ${ }^{120}$ It condemned the legal system's acceptance of husbands' right to control their wives as an unlawful suspension of the writ of habeas corpus, for example. ${ }^{121}$ On this point and others, the 1876 Declaration drew on arguments presented in the Minor case, framed in language that aligned with nascent liberal understandings of individual liberty and equality.

\section{The Dual Campaign}

The failure to win inclusion in the Reconstruction Amendments adopted by Congress and the defeat in Minor left women's rights advocates with no choice but to redirect their activities back to the states. Women's rights campaigns returned to being highly localized, grassroots, diffused movements that involved continuous engagement with state legislatures, petition gathering, and state referenda, with efforts directed to both changing the law of marital relations and obtaining the vote. ${ }^{122}$ But there was one difference compared to the pre-war era: the movement's priorities traded places and suffrage became more the end and mobilizing opposition to the power of coverture more the means.

Nonetheless, when women approached state lawmakers, "they brought marital property arguments along with them."123 The suffrage movement continued after the Civil War to be a joint suffrage and marriage-reform movement. Movement publications reflected the joint priorities, as did reports from state associations. ${ }^{124}$ The self-styled suffrage organizations led the legislative fights on both issues and monitored court decisions interpreting the new marriage laws.

118. See Declaration of the Rights of Women of the United States - July 4, 1876, IowA ST. UNIV. ARCHIVES OF WOMEN's POL. COMM., https://awpc.cattcenter.iastate.edu/2017/03/21/declaration-ofrights-of-the-women-of-the-united-states-july-4-1876/ [https://perma.cc/PJ8G-XUD7] (last visited Apr. 21, 2020).

119. DeClaration OF SENTIMENTS (1848), supra note 19, at 70.

120. Declaration of the Rights of Women of the United States - July 4, 1876, supra note 118.

121. See id.

122. See Nancy Woloch, Women And the American Experience 332-33 (1984) ("The Minor decision made it clear that the 'new departure' had no future. . . Agitation on the state level was by no means a total loss, however, since many legislators were willing to vote for a wide array of legal reforms affecting women, indeed, for virtually anything except suffrage. . . [L]egal reform was far easier to accept than the highly charged vote.").

123. Siegel, supra note 55, at 1168.

124. Id. at 1168-77. 
Progress in achieving both goals, however, was slow. The state-by-state process, combined with numerous variations in language and scope, made progress in enacting married women's property acts halting and piecemeal. ${ }^{125}$ Moreover, the married women's property acts were amended multiple times, ${ }^{126}$ sometimes to advance women's rights, other times to curb them. ${ }^{127}$ State courts tended to interpret the married women's property acts narrowly. ${ }^{128}$ Nonetheless, by 1890 , thirty-three states and the District of Columbia had enacted some version of a married women's property act. ${ }^{129}$

Progress on suffrage was also glacial. Between 1870 and 1910, 480 petition campaigns to put referendum questions on state ballots resulted in only seventeen referenda, only two of which secured votes for women. ${ }^{130}$ Legislation granting the vote was adopted initially for school-board and municipal elections, and then within territories and states in the West. ${ }^{131}$ The first state east of the Mississippi River to grant women full suffrage was New York in 1917. ${ }^{132}$

Between the end of the Civil War and the adoption of the Nineteenth Amendment, the achievement of the greatest political significance was the process itself. Debate and contestation over the proper role of women as citizens and the proper allocation of rights within marriage drew in many thousands of Americans. Based on organizational records, the National Women's Party enrolled approximately two million members in $1917 .{ }^{133}$ Both as protest and law reform, the campaign for suffrage changed the culture as well as the law of gender, affecting both the rules of governance and the subjective identities of the women who participated. ${ }^{134}$

It was a deeply compromised movement, however, that produced even the most progressive changes. The suffrage campaign grew increasingly conservative as many white suffrage advocates argued that white women's enfranchisement

125. CoTT, supra note 5, at 53-54; Richard Chused periodized the enactment of the married women's property acts in three waves: first, laws that "freed married women's estates from the debts of their husbands," then the creation of "separate estates for married women," and finally laws protecting the earnings of married women. See Chused, supra note 39, at 1398.

126. In New York alone, the initial 1848 statute was amended nine times. Siegel, supra note 41, at 2149.

127. Id.

128. See Chused, supra note 39 , at 1400.

129. See DEGLER, supra note 10, at 332-33; WOLOCH, supra note 122 , at 333

130. See EvANS, supra note 24, at 153.

131. KRADITOR, supra note 20, at 4-5.

132. Id. at 6. The Illinois legislature amended its law in 1913 to allow women to vote for presidential electors. Id.

133. Id. at 7. In 1920, the U.S. female population was just under fifty-two million. HoBBS \& STOOPS, supra note 3, at A-13 tab.6 pt.B. The 2017 female population was almost 166 million. Total Population in the United States by Gender from 2010 to 2024, STATISTA, https://www.statista.com/statistics/737923/ us-population-by-gender/ [https://perma.cc/Y9XY-WLLT] (last visited Apr. 21, 2020). A rough calculation indicates that a comparably sized organization today would have more than six million members.

134. Historian Ellen DuBois argues that: “[i]t was women's involvement in the suffrage movement, far more than ... enfranchisement ... that created the basis for new social relations between men and women." See WOLOCH, supra note 122, at 358. 
would shore up white supremacy ${ }^{135}$ and outnumber male immigrants who could become citizens. ${ }^{136}$ Racist and nativist arguments by suffragists were not new, ${ }^{137}$ but the post-war shift was of a piece with a wider retrenchment in political support for human rights after Reconstruction. African-American suffragists, together with white women who rejected racist arguments, battled with other whites who seized on what historian Aileen Kraditor called "expedient" tactics for attracting more supporters, especially but not only in the South. ${ }^{138}$

Another reason for the changing tenor of pro-suffrage arguments was the changing composition of the movement. As the years passed after the end of the Civil War, fewer of its leaders had personal links to the anti-slavery movement. The newer and younger leaders were more likely to be simultaneously involved with the temperance campaign. ${ }^{139}$ Temperance was the other large women-led political movement of the time. ${ }^{140}$ By the end of the nineteenth century, debates on suffrage and the social role of women often included arguments of women's moral superiority as a reason for enfranchisement. ${ }^{141}$

Moreover, the broader culture was changing in ways that profoundly affected women. The growth of cities produced a new class of young women with greater personal freedom and access to paid employment. ${ }^{142}$ For middle-class women, the expansion continued of educational and professional opportunities. ${ }^{143}$ Although the racial barriers were stark, the same processes occurred on a smaller scale for African-American women. ${ }^{144}$ Divorce, although still rare, increased

135. See KRADITOR, supra note 20, at 52 ("The suffragists . . . . found that the 'best' argument of native-born, white, middle-class women was one which would prove their own capacity but not that of men or women of the other sections of the population."); MARILLEY, supra note 28, at 161 .

136. See Marilley, supra note 28, at 178-80; William L. O'Neill, Everyone Was Brave: A History OF FEMINISM IN AMERICA 71-74 (4th prtg. 1971).

137. See MARILley, supra note 28 , at 49.

138. See KRADITOR, supra note 20, at 52 ("The start of the twentieth century may be taken as the turning point in the change from justice to expediency as the chief argument of the suffragists."); MARILLEY, supra note 28, at 161.

139. KRADITOR, supra note 20, at 56-58.

140. See EVANS, supra note 24, at 125-30, 148-52; O'NeILL, supra note 136, at 77.

141. See EvANS, supra note 24, at 154 . The 1876 Declaration, for example, asserted morality-based claims for the redress of women's grievances. See, e.g., Declaration of the Rights of Women of the United States - July 4, 1876, supra note 118 ("During the temperance crusade, mothers were arrested, fined, imprisoned, for even praying and singing in the streets, while men blockade the sidewalks with impunity, even on Sunday, with their military parades and political processions. ...Woman's degraded, helpless position is the weak point in our institutions to-day; a disturbing force everywhere, severing family ties, filling our asylums with the deaf, the dumb, the blind; our prisons with criminals, our cities with drunkenness and prostitution; our homes with disease and death.").

142. See WolOCH, supra note 122, at 231-34 (noting that in large U.S. cities, immigrant women found employment in factories, mills, and domestic settings).

143. Id. at $276-87$.

144. See generally Evelyn Brooks Higginbotham, Clubwomen and Electoral Politics in the 1920's, in ANN D. Gordon ET AL, AFRICAN-AMERICAN WOMEN AND tHE Vote, 1837-1965 (1997) (describing increase in the number and influence of middle-class African-American women); Christina Simmons, "Modern Marriage" for African Americans, 1920-1940, 30 CANAdian REV. AM. Stud. 273, 285-87 (2000). 
substantially, with wives composing a large majority of plaintiffs. ${ }^{145}$

\section{Winning One Fight, Continuing the Other}

In the early years of the twentieth century, the dual suffrage-marriage reform campaign continued, intertwined but increasingly distinct. Suffragists prioritized a national strategy, developed and centered in Washington, that coordinated state campaigns for the vote along with lobbying for Congressional adoption of a suffrage amendment. The Nineteenth Amendment constituted both an enormous achievement and, by the sense of moving on that the success produced, a loss of a clear national focus for women's rights advocates. Again, seeking reform in marriage and family laws, they returned to the states.

\section{A. THE TIPPING POINT}

With new national leadership, suffragists developed a broad repertoire of strategies and tactics, from sophisticated interest-group-style lobbying of lawmakers and strategizing with the staff of the President, to picketing the White House. ${ }^{146}$ When he was first elected in 1912, President Woodrow Wilson opposed women's suffrage, but his position evolved during his time in office to one of complete support. ${ }^{147}$

World War I tipped the political balance in favor of the Nineteenth Amendment. In President Wilson's narrow framing, the primary justification for the Nineteenth Amendment was the fairness inherent in payment of a debt. Notably, the debt around which he organized this message was itself contingent upon women venturing beyond the domestic sphere. Wilson told Congress that:

We have made partners of the women in this war .... This war could not have been fought, either by the other nations engaged or by America, if it had not been for the services of the women-services rendered in every sphere-not merely in the fields of effort in which we have been accustomed to see them work, but wherever men have worked and upon the very skirts and edges of the battle itself. We shall not only be distrusted but shall deserve to be distrusted if we do not enfranchise them with the fullest possible enfranchisement, as it is now certain that the other great free nations will enfranchise them. . . I I propose it as I would propose to admit soldiers to the suffrage, the men fighting in the field for our liberties and the liberties of the world, were they excluded. The tasks of the women lie at the very heart of the war ... ${ }^{148}$

145. See Degler, supra note 10, at 168; PAul H. JaCobSOn, American MARriage And Divorce 119-20 (1959).

146. See COTT, supra note 5, at 53; EvANS, supra note 24, at 166-70; MARILLEY, supra note 28, at 211-16.

147. Christine A. Lunardini \& Thomas J. Knock, Woodrow Wilson and Woman Suffrage: A New Look, 95 PoL. SCI. Q. 655, 657 (1980-1981). Historians believe that Wilson was motivated to change his views by some mixture of persuasion by suffragists and concern about the election prospects of the Democratic Party as more states allowed women to vote. Id. at 670-71.

148. Woodrow Wilson, Address to the Senate on the Nineteenth Amendment: (Sept. 30, 1918), AM. PRESIDENCY PROJECT, https://www.presidency.ucsb.edu/documents/address-the-senate-the-nineteenthamendment [https://perma.cc/J565-UZUD] (last visited Apr. 22, 2020). 
World War I marked the first significant involvement of women in national defense outside of the field of nursing. During the war, eight million women were employed in 437 job classifications. ${ }^{149} \mathrm{New}$ women's divisions in the Army ordinance agency and the Railroad Administration were established. ${ }^{150}$ For privatesector workers, some employers set up the first day nurseries to enable greater productivity in key industries. ${ }^{151}$

This demand for labor during the war marked a new stage in economic citizenship for women. For the first time, the national government recruited women to leave their homes to fill non-domestic, non-gender-typical jobs. ${ }^{152}$ World War I legitimated women's paid employment as an essential national-defense function and a shared civic need, and linked the fate of the nation to the ability of women to work outside the home. In the masculinist terms of an argument used by opponents of suffrage, women gained admittance to a proxy for military service, which some argued was historically viewed as a precondition for the right to vote. $^{153}$

The text of the Nineteenth Amendment addresses only the vote, the direct product of the suffrage-focused component of the Women's Rights Movement. But the Amendment's adoption in 1920 validated both the new political subjectivity of women and the growing acceptance that women had a social and economic existence outside the family. For both its supporters and opponents, the Amendment "involved breaking with common law traditions that subordinated women to men in the family and intervening in domestic matters traditionally reserved to state control." 154 Even the most conservative or transactional interpretation of the Nineteenth Amendment implicitly rebutted the discourse of domesticity exemplified in Justice Bradley's reference to "the constitution of the family" in Bradwell. ${ }^{155}$

\section{B. EQUALITY AS ONGOING PROCESS}

In the wake of the Nineteenth Amendment, feminists turned to the vestiges of coverture that remained, as well as other discriminatory laws. The goal of eliminating class-wide legal discrimination against women ${ }^{156}$ continued the movement's strategic focus on the state-family nexus of power, and specifically the limitations on both exit from marriage and on entry to the paid workforce. Suffragists persisted in their efforts to change state laws. ${ }^{157}$ The project of

149. William Henry Chafe, The American Woman 49 (1972).

150. See Maurine Weiner Greenwald, Women, War, And Work: The Impact of World War I ON WOMEN WORKERS IN THE UNITED STATES 47, 57-60 (1990).

151. See Sonya Michel, Children's Interests/Mothers' Rights: The Shaping of America's Child Care Policy 88 (1999).

152. GREENWALD, supra note 150 , at 32-35.

153. KRADITOR, supra note 20, at 28-29.

154. Siegel, She the People, supra note 2, at 1045.

155. Bradwell v. Illinois, 83 U.S. (16 Wall.) 130, 141-42 (1872).

156. NAncy F. Cott, The Grounding of Modern Feminism 75-76 (1987).

157. Susan D. Becker, The Origins of the Equal Rights Amendment: American Feminism BETWEEN THE WARS 18-19, 129 (1981). 
marriage-law reform remained piecemeal and unwieldly: a decade after suffrage, seventeen states continued to treat husbands and wives differently in the sale of real estate and, in 1940, almost a quarter of states did not permit wives to contract. $^{158}$

Reasoning that another new provision in the Constitution could invalidate these laws in one preemptive strike, the National Woman's Party (NWP) voted to dedicate itself to securing an Equal Rights Amendment (ERA). ${ }^{159}$ The Declaration of Principles adopted at the NWP's 1922 conference essentially updated the 1848 Seneca Falls Declaration with a comprehensive statement of post-suffrage demands. ${ }^{160}$ Although less well-known than the Seneca Falls Declaration, the 1922 Declaration of Principles set the modern terms of debate on women's rights until the Second Wave feminists emerged in the 1960s.

The 1922 Declaration begins and ends with explicit invocations of equality, and the concept of women's equality with men structures each of its twenty-eight demands. ${ }^{161}$ Arguments on freedom from intimate domination remain, ${ }^{162}$ but the goal of liberty from tyranny in the domestic sphere dating from the Declaration of Sentiments had fully morphed into one of equality under law. Roughly the first half of its enumerated demands cover non-marriage issues such as employment and education, but the largest thematic component of the overall content addresses legal issues related to marriage. The first draft of the proposed ERA continued to address marriage as the legal issue of primary concern by explicitly combining equality and marriage: "No political, civil or legal disabilities or inequalities on account of sex, or on account of marriage unless applying alike to both sexes, shall exist within the United States or any place subject to their jurisdiction."163

Feminists achieved the only major judicial acknowledgment of the Nineteenth Amendment as recognition of revolutionary change in women's legal status in Adkins v. Children's Hospital. ${ }^{164}$ The Court's opinion adopted the position that women had the same liberty to contract as men in its striking down of a minimum wage law only for women, referring to "the great-not to say revolutionarychanges which have taken place ... in the contractual, political, and civil status

158. DEGLER, supra note 10, at 333; see also generally Joseph Warren, Husband's Right to Wife's Services, 38 HARV. L. REV. 421 (1925) (describing a variance in state law as to whether husband could relinquish his right to his wife's services in his business, and uniformity of the absence in state law of allowance for relinquishment of his right to wife's services in the home).

159. Susan D. Becker, The Origins of the Equal Rights Amendment: American Feminism BETWEEN THE WARS 18-21 (1981).

160. See Declaration of Principles of the National Woman's Party. Adopted at the Conference of National and State Officers of the Woman's party, Washington, D.C., November 11, 1922, LIBRARY OF CONG., https://cdn.loc.gov/service/rbc/rbpe/rbpe20/rbpe208/2080340a/2080340a.pdf [https://perma.cc/ M33T-4X2Z].

161. See id.

162. See id.

163. Nancy F. Cott, Historical Perspectives: The Equal Rights Amendment Conflict in the 1920s, in Conflicts in Feminism 44, 47 (Marianne Hirsch \& Evelyn Fox Keller eds., 1990).

164. 261 U.S. 525 (1923). 
of women, culminating in the Nineteenth Amendment." ${ }^{165}$ Few courts or legislatures followed suit, however, instead reverting to a discourse of domesticity. ${ }^{166}$

The campaign was incomplete in a second sense as well: the predominantly white ERA advocates paid little attention to the realities of married life for African-American women. In a system that was highly racialized even where it was not formally segregated, the marriage construct operated differently for African-American women than for white women, creating opposite expectations. The dynamics of racial capitalism produced a system in which black women often worked outside their own homes for little money, most frequently in the homes of white women, whose quality of life benefitted directly from the domestic incarnation of racial subordination. ${ }^{167}$ The system also reinforced the higher "family wage" earned by white men and enabled the restriction of black men to low-wage jobs while still allowing black families to subsist on minimal earnings. ${ }^{168}$

It is also true that marriage itself had become a more complex reality, although the legal rules for allocating power and resolving disputes had changed only partially. Companionate marriage-a union of partners, even if the degree of equality remained obscure-began to emerge as the new cultural model for American couples. ${ }^{169}$ In many respects, however, the social understanding of companionate marriage was of an updated version of separate spheres, with complementary and gendered roles for each spouse. ${ }^{170}$ Progressive Era reformers invoked women's experience and capabilities in managing the domestic sphere as needed to properly manage similar issues, such as health and charity, in the public sphere. ${ }^{171}$

\section{The Nineteenth Amendment in the Twenty-First Century}

The dual campaign for suffrage and marriage-law reform that produced the Nineteenth Amendment created a link between the Constitution and the institution of marriage that has untapped potential to shape judicial interpretations of the regulation of marriage and family law. That this potential remains dormant was illustrated by the decision in Obergefell v. Hodges, in which the Supreme Court ruled that states must permit same-sex couples to marry based on the liberty and equality rights of the partners. ${ }^{172}$ The Court discussed coverture and the internal dimensions of marriage law only twice, both times superficially.

165. Id. at 553 .

166. Siegel, She the People, supra note 2, at 1017-19.

167. JaCQueline Jones, Labor of Love, Labor of Sorrow: Black Women, Work AND THE

FAMILY, FROM SLAVERY TO THE PRESENT 135, 139, 142 (2d ed. 2010).

168. Alice Kessler-Harris, A Woman's Wage: Historical Meanings \& Social Consequences

9, 122 (1990); see also JONES, supra note 167, at 140.

169. See Evans, supra note 24, at 177-78; Steven Mintz \& Susan Kellogg, Domestic

Revolutions: A Social History of American FAMily Life 126 (1988).

170. Siegel, supra note 41, at 2201-10.

171. KRADITOR, supra note 20 , at $68-70$.

172. 135 S. Ct. 2584, 2602-03 (2015). 
First, the Court noted that coverture had been "abandoned" with the acceptance of "equal dignity" for women. ${ }^{173}$ Despite a singularly passive construction that acknowledged nothing of the history of how or why that change had occurred, the context for the comment was a recognition that the structure of marriage had evolved greatly over time, producing changed understandings of its social meaning.

The second reference to coverture came in the context of discussing the relevance of the Equal Protection Clause to the case before it. The opinion first declared that the equality guarantee provides an enhanced understanding "as to the meaning and reach" of the fundamental liberty right to marry. ${ }^{174}$ The Court then turned to its only analysis of the equality rights of partners within marriage. The following passage suggests a partial predicate for a constitutional theory of marriage:

Notwithstanding the gradual erosion of the doctrine of coverture ... invidious sex-based classifications in marriage remained common through the mid-20th century. ... These classifications denied the equal dignity of men and women. ... Responding to a new awareness, the Court invoked equal protection principles to invalidate laws imposing sex-based inequality on marriage.... [T]hese precedents show the Equal Protection Clause can help to identify and correct inequalities in the institution of marriage, vindicating precepts of liberty and equality under the Constitution. ${ }^{175}$

What the Court could have done at this point in its analysis was draw on the understandings of marriage that emerged in the dual campaign for suffrage and marriage reform that found constitutional purchase in the Nineteenth Amendment. In both its references to coverture in Obergefell, the Court's omission of how and why coverture ended is striking. The opinion referred to "unjustified inequality within our most fundamental institutions that once passed unnoticed and unchallenged." ${ }^{\prime 76}$ Because the next sentence references the challenges based on sex discrimination during the 1970 s and $1980 \mathrm{~s},{ }^{177}$ one is left wondering whether all the Justices are even aware of the Declaration of Sentiments and the full scope of the movement that it generated.

More importantly, both women's rights advocates and lesbian and gay rights advocates noticed and challenged the legal construction of marriage as an institution in a more thoroughgoing way than the Court suggested. The two movements addressed both the internal or endogenous aspects of marriage law, such as coverture, and the external or exogenous aspects of marriage law, including its interrelationship with property law. What most powerfully links the two movements is that both sought to force the state to regulate marriage as an institution subject to

173. Id. at 2595 .

174. Id. at 2602-03.

175. Id. at 2603-04 (citations omitted).

176. Id. at 2603.

177. Id. 
the principles of constitutional governance, including, to use the Court's phrase, "precepts of liberty and equality under the Constitution." 178

In the nineteenth century and well into the twentieth century, the endogenous aspects of marriage law included the creation of a legal status that produced a position of de jure inferiority for all women, married and unmarried. By the time of Obergefell, the gender-linked legal statuses of husband and wife had fallen away. ${ }^{179}$ Same-sex couples seeking to marry were challenging their eligibility to do so, but not the regulation of interspousal relationships.

The parallel law of property as an exogenous dimension of marriage law runs throughout the history of both movements. In the last century, its importance has increased as marriage has become the linchpin of systems of social insurance that did not exist at the time of the Nineteenth Amendment. Marriage and marital status were fully integrated into the design of the Social Security system and unemployment insurance. ${ }^{180}$ Social Security and other benefits programs, together with tax law, account for the bulk of the more 1,000 instances of the reliance of federal law on marital status. ${ }^{181}$ Private insurance law, reflected in employee health insurance plans, also routinely uses marital status to define coverage. By the 1980s, when LGBT rights groups began to direct attention and advocacy efforts toward recognition of same-sex relationships, the denial of eligibility for benefits, especially health insurance, became a key argument in litigation and lobbying efforts. ${ }^{182}$ Whereas marriage, through coverture, had once robbed women of the material benefits associated with their property and earnings, by the current century marriage had been redeployed as a structural component of public and private sources of material support.

In defense of the Court's traditionalist, almost folksy language in Obergefell, one can point to the discursive strategy used by the same-sex marriage campaign to emphasize that its goal was not to change marriage. ${ }^{183}$ In the later stages of both movements, advocates for same-sex marriage and suffrage mixed arguments for rights with arguments steeped in respectability and morals. The Obergefell opinion embodies precisely that approach, which I would call a rhetoric of

178. Id. at 2604.

179. See Nan D. Hunter, Marriage, Law and Gender: A Feminist Inquiry, 1 L. \& SEXUALITY 9,16 (1991).

180. Alice Kessler-Harris, In Pursuit of Equity: Women, Men, And the Quest for Economic CitizEnSHIP IN 20TH-CENTURY AMERICA 98-99, 120-21, 136-41, 292-93 (2001); Alice Kessler-Harris, Designing Women and Old Fools: The Construction of the Social Security Amendments of 1939, in Linda Kerber ET AL, U.S. History AS WOMEN's History 87, 87-106 (1995).

181. U.S. Gov't Accountability OfFice, Defense of Marriage Act: Update to Prior Report 1 (2004), https://www.gao.gov/products/GAO-04-353R [https://perma.cc/2V6W-GZ23].

182. Walter Isaacson, Should Gays Have Marriage Rights?, Time, Nov. 20, 1989, at 101-02, http:// www.unmarriedamerica.org/Archives/1972-2005-TFC-News-Stories/1989-Time-Gay-Marriage.pdf [https://perma.cc/6HAE-HF26]; see also, e.g., Nat'l Pride at Work v. Governor of Mich., 748 N.W.2d 524 (Mich. 2008) (describing efforts to secure partner benefits through collective bargaining, city ordinance, and university policy as well as subsequent litigation regarding the impact of a state constitutional amendment prohibiting same-sex marriage).

183. See Nan D. Hunter, Varieties of Constitutional Experience: Democracy and the Marriage Equality Campaign, 64 UCLA L. REV. 1662, 1719-20 (2017). 
reassurance. Reassurance may be politically appealing — even necessary-for the success of social movements and the popular legitimacy of the Court. But the Court also has a responsibility to acknowledge the full force of the social movements upon which it relies for the normative justifications for its decisions. The lesson of Obergefell-like the lesson of the Nineteenth Amendment-should not be that nothing much has changed.

Additional questions concerning the regulatory aspects of marriage are likely to arise in the future. Some may concern auxiliary issues related to same-sex couples. ${ }^{184}$ Or, the centrality of marriage to social insurance may create circumstances in which access to those forms of property may be in dispute. Whatever the context, and the possibilities are extensive, understanding the body of constitutional law applicable to marriage as a legal and social institution and the extent to which the Nineteenth Amendment strengthens its regulation in accordance with constitutional norms, should be at the heart of the Court's analysis.

\section{CONCLUSION}

The path of social movements is not linear, and the history of the campaign that led to the Nineteenth Amendment is no exception. It began and remained a two-pronged effort for both suffrage and marriage-law reform. Contested understandings of marriage as a legal and social institution were central to the public meaning of the Nineteenth Amendment. As a result, women's rights and marriage reform have a unique relationship in our constitutional history.

This Article seeks to return marriage to the center of our understanding of the Nineteenth Amendment and to incorporate the history and context of the Nineteenth Amendment into our understanding of the legal institution of marriage. Doing so would provide a richer and more persuasive basis for invalidating the exclusion of same-sex couples. Today, just as women are no longer defined by marriage, marriage is no longer defined by gender. Neither change could have occurred without the other.

184. See, e.g., Pavan v. Smith, 137 S. Ct. 2075, 2078 (2017) (per curiam) (recognizing a right of both same-sex spouses to be listed as parents on their child's birth certificate). 